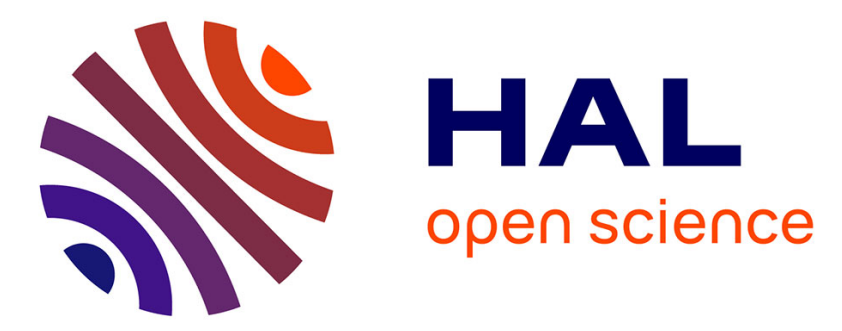

\title{
Political Patronage and Ritual Competitions at Dussehra Festival in Northern India
}

\author{
Daniela Berti
}

\section{To cite this version:}

Daniela Berti. Political Patronage and Ritual Competitions at Dussehra Festival in Northern India. Christiane Brosius and Karin Polit. Ritual, Heritage and Identity:The Politics of Culture and Performance in a Globalised World, Sage, India, pp.126-148, 2011. hal-00627913

\section{HAL Id: hal-00627913 https://hal.science/hal-00627913}

Submitted on 29 Sep 2011

HAL is a multi-disciplinary open access archive for the deposit and dissemination of scientific research documents, whether they are published or not. The documents may come from teaching and research institutions in France or abroad, or from public or private research centers.
L'archive ouverte pluridisciplinaire HAL, est destinée au dépôt et à la diffusion de documents scientifiques de niveau recherche, publiés ou non, émanant des établissements d'enseignement et de recherche français ou étrangers, des laboratoires publics ou privés. 
[Preprint version 2010]

[In C. Brosius and K. Polit (eds.). Ritual, Heritage and

Identity.The Politics of Culture and Performance in a

Globalised World, pp. 126-148. Delhi: Sage, 2011]

Political Patronage and Ritual Competitions at Dussehra Festival in Northern India

Daniela Berti

The relevance of rituals to define regional identities in India can be traced back to early medieval times. By considering some Jain Sanskrit texts from the 11th to the 16th century, Granoff (2001) shows how ritual distinctions were used for expressing what were primarily territorial, political or geographical oppositions (Granoff 2003). Inversely, rituals in medieval India also served to unite territorially and politically based distinctions. This is shown, for example, by the inclination of Hindu kings to select an existing local cult and to apply it to the whole territory of their kingdom by means of royal patronage (Kulke 1986).

The importance of rituals to mark, either by separating or uniting, territorial and political identities, was also recognised by post-colonial nationalist leaders. Immediately after Independence, many of them pursued the idea of national unity through ritual along with constructing — in some cases, redefining — regional specificities. By the 1960s or 1970s, depending on the region, the organisation of most royal festivals once patronised by kings was taken up by local politicians who requested regional governments to fund festival committees. These government-sponsored festivals became the ideal framework in which a local politician could play a symbolic role, either by completely assuming the role of former kings or by sharing the festival's public space with them, in a more or less competitive way.

This political appropriation of royal festivals took place along 
with a discourse on the safeguarding and revitalisation of regional culture, well in consonance with the national (and international) valorisation of local costumes and cultural, ethnic differences. In some regions, this 'revival' led to the transformation of the royal festival into a 'cultural' or 'folk' festival, by including different sorts of entertainment — artistic programmes, cultural forums, exhibitions and competitions. The festival committee managed a kind of 'heritage industry'. Its task was no longer limited to organising the festival's ritual line-up, but also to add cultural value to it (Kirshenblatt-Gimblett 1995) and present its revival as crucial to the survival of an alleged local memory and a regional cultural identity.

In this article, I will discuss a case which illustrates how the passage from religious festival to cultural programme is the result of a historically complex process involving different actors and mediations at different levels of society.

I will focus my observations on a royal cult in the Indian Himalayas - the Kullu Dussehra - established in the 17th century by a local king. At the beginning of the 1970s, it was nationalised and promoted as a national, then even international, 'folk dance festival'. Like many other examples of heritage production, the case I present here is neither an anonymous nor a spontaneous process. It has been consciously selected and set up by political leaders and local notables, not without causing some tension or even confrontation between other members of local society whose disagreement had different motivations and took up multiple forms.

I will retrace the history of this controversial process not only by locating the main actors and the ritual and political stakes which are behind it, but by contextualising this local event within the wider national cultural framework to which it is strictly related.

My concern here is on local debates about heritage and tradition, and how they took form in a specific regional context. In order to do so, I draw upon a selection of newspaper cuttings, and on narratives of people who took part in the cultural promotion of the Dussehra festival.

In the first part of this article, I show how this transformation of 
the Kullu Dussehra needs to be understood by situating it in relation to a national cultural and political context - for instance, in relation to the cultural politics of the Nehru government on the occasion of the annual Republic Day parade. I will also examine political stakes behind this transformation by introducing some of the main personalities involved in the festival's revival, from the 1970s onwards. ${ }^{1}$ The second part of the article shows how media coverage of the festival is intentionally appropriated by different groups of villagers in order to publicly display and act out longstanding conflicts and rivalry between villages as well as between villagers and local authorities. This provoked a public debate in the local newspapers about what is alternatively called Kullu heritage or tradition.

\section{The Context}

In many parts of India, Dussehra is celebrated every year during the months of September-October. From a mythological point of view, the festival is supposed to commemorate two episodes of the Sanskrit textual tradition - the victory of Durga over the demon buffalo Mahishasura and, often in an overlapping way, the victory of the god-king Rama over the demon-like king Ravana. Although performed as a religious festival, Dussehra is also a ritual idiom of kingship, symbolically representing the consecration and legitimation of royal or political power. The Dussehra festival assumes different local forms, depending on the various former kingdoms in which it is performed.

In the Kullu district in Himachal Pradesh, the Dussehra festival is the occasion when all village deities, represented by their decorated wooden palanquins, are brought to the capital by villagers in order to pay homage to the king and to the royal god. ${ }^{2}$ In local sources, this festival appears to have been introduced in the region by a 17th century Kullu king, Jagat Singh, who dedicated the kingdom to the god Raghunath (an epithet of the god Rama), in the name of whom he started to rule. He also provided village gods 
with land rights, requiring them to pay an annual tribute to Raghunath and to participate in the festival. Villagers and their deities had to go to the capital, to take part in the rath yatra, a major procession with Ram's chariot, and to attend the darbar, a royal assembly held by the king during the festival. In the pre-colonial period, participation by these village gods in the six-day Dussehra celebrations was compulsory, and defaulting deities had to pay a fine to the king. They also had to pay an annual tribute to Raghunath (nazrana). ${ }^{3}$ Moreover, many devotional and ritual ties had been forged between the person of the king and the village gods, which were expressed at the time of the festival. A number of local stories recount how, for example, a village god was eventually attributed an honourific position during the festival, for having satisfied one of the raja's (king) personal requests.

Along with this political and religious dimension, the Kullu Dussehra included an entertaining component, which consisted in performing dances (nati) accompanied by different kinds of village songs. Each village participating in the festival had a group of dancers, villagers who danced just for their own enjoyment (Singh 1992). Each group of dancers was associated with a god, although the content of the song accompanying the dance was not religious, but rather dealt with love or other sentimental themes.

Kullu writers and politicians present the history of the festival's radical transformation as being marked by a single crucial factor. According to them, the festival was about to disappear after Independence following a series of land reforms passed by the Indian government. Among other consequences, this leads to an impoverishment of village gods. As far as the events are presented by local people, this situation was the main reason why some villagers stopped bringing their deities to the Dussehra; they could no longer endure the cost of staying in the capital for the festival period of six days. At the beginning of the 1960s, L.C. Prarthi, a Brahmin politician of the Congress party who repeatedly served as a minister in the regional government of Himachal Pradesh and was an elected MLA (member of the region's Legislative Assembly), elaborated a discourse 'on the survival of regional traditions'. The 
intention was to obtain funds for keeping alive what he considered to be 'the most important cultural heritage of the Valley', that is the Kullu Dussehra. Prarthi's efforts to revive Dussehra reflected conceptions of post-Independence political leaders and Delhi's intellectuals about 'regional folklore'. Let us consider their main points, and how such conceptions influenced the reorganisation of the Kullu festival.

\section{Folk Dances and Public Space}

The idea of 'nationalising' Dussehra is part of a political project which started back in the colonial period, when some festivals in different parts of India began to be perceived as a means of creating a political feeling of Indian unity, thus becoming 'national festivals'. This is shown, for example, in an article entitled 'Nationalise our Festivals' published in The Tribune as early as 1922. Here, the author appeals to a 'true love of unity' in order to 'nationalise' what he presents as a festival likely to be 'common to all Indian communities', i.e. Dussehra.

Immediately after Independence, the Nehru government chose to create several public occasions to underline and exalt the diversity of regional cultures of India, while putting them at the service of unity and national integrity. In his unpublished thesis, Ashley (1993) shows how on Republic Day in Delhi, for example, a 'folk dance festival' was organised to stage dances from different regions of the country, including dances from Kullu. Folk dances were also included in the parade performed on this occasion. Ashley notes how the 'float' representing the military and technological power of India was at the front of the parade to signify India's present/ future, whereas folk dances were to be found at the back of the line to signify India's past, to 'remind India' as the Delhi parade newscaster himself put it, 'of its roots in the soil' (Ashley 1993: 259; see also Jain, 2008).

This way of situating the 'Indian past' in regional folklore is underlined by an editorial dated 1955 with the title 'The Future of 
Our Folk Art', where Indian villages are presented as ideal harmonious societies and folk culture as 'the most living and genuine part of Indian cultural heritage' (Ashley 1993: 275), which can thus be used to construct a notion of national culture as 'real':

There was a time when things of beauty made by our village people used to be looked down upon by educated city-bred men, bhadralok, as they were called... It will take some time for good taste to grow. And our folk art can contribute to that with its innate sense of form, of design, of pattern. It is true that this sense of form or design has grown out of the functional work of generations of men and women in the midst of their integral community life with its total pattern. This was possible because the impact of British rule could not completely wreck the life of our villages and the culture and the arts of village folk (Bishnu Dey 1955: 10, quoted in Ashley 1993: 275).

Similarly, we read in an official Republic Day brochure that village communities and particularly 'folk dances and songs' are likely 'to preserve the genius of the Indian tradition and cultural heritage in its very pristine form' (Ashley 1993: 280). This introduction of the 'local' into a national parade, and the equivalence made between 'local', 'past' and 'authentically Indian', was for the leaders of the time a way to enable people from distant tribes and villages to acquire a feeling of solidarity with other Indians (Ashley 1993: 268), to officially expose and stage a model of national integrity based on the principle of 'unity in diversity' (Ashley 1993: 296). Ashley (1993: 268) quotes from a passage by Jawaharlal Nehru who wrote 'the idea of several hundred folk dancers from different parts of India coming to Delhi brings home to them and to all of us the wealth of our cultural heritage and the unifying bond which holds it together'.

Nehru;s discourse corresponds to what was happening throughout India at the time. But the more we look at the micro-scale, the more we find that along with this rhetoric on national construction, it is important to consider the protagonists' local dynamics and personal motivations in this process. As far as Kullu is concerned, the 
main points of the Republic Day's rhetoric are reproduced in the discourses concerning the nationalisation of the Dussehra festival as they appear in articles from local newspapers. In 1966, when Kullu became part of Himachal Pradesh, L.C. Prarthi decided to reorganise the Kullu Dussehra by promoting the entertainment element of the festival, i.e. the nati. As noticed by M. Sharma, Director, Centre for the Arts (Kala Kendra) in Kullu :

During Dussehra, people used to spend the whole night singing and dancing, near their village deities. Every village deity (coming to Dussehra) brought with him a folk dance group. People danced and enjoyed themselves throughout the night. They were just villagers who were interested in culture. People used to dance very close to each other. They all blocked their ears as they sang, just for fun.

In 1972, Prarthi ordered the construction of a Kala Kendra Centre for the Arts - in Kullu, an outdoor amphitheatre which staged cultural programmes and dance competitions. He also received funds from his leader and friend, Himachal Pradesh Chief Minister Y.S. Parmar, who is himself presented in many newspapers as an 'ardent lover of Pahari (mountain) culture'. The funds aimed at enabling village dance groups to come to the Dussehra, and at organising a 'folk dance competition'. From then on, 'folk dance parties' from Kullu as well as from other regions of India came to be selected by a committee, and competed for a price.

Prarthi is presented as the 'pioneer of a group of art lovers' and as a 'dedicated artist' — he was also a poet — who lent a 'complexion of culture to the celebrations' ${ }^{11}$; he considered folk dances to be 'natural to the sons and daughters of the mountains'. His valorisation of regional culture presents clear similarities with the editorial published for the Republic Day parade in Delhi, as shown by a passage from one of his articles entitled 'Revival of Folk Culture':

With the constantly mounting influence of outsiders and as a result of creating an inferiority complex among local people with regard to their culture, folk dances etc. in Kullu district had almost ceased to be around the year 1952. Local leaders, particularly those 
interested in the preservation of the valley's rich culture were alarmed at this development, which they felt would result into wiping a culturally distinct unit off the map of the country. Consequently a movement started and concerted efforts were made to infuse a spirit of self-respect and honour for their culture among the people of Kullu district. They were made to understand that their culture was not only rich but worth emulation by other people in the country. Gradually the image of folk culture began to regain its stature and prestige in the area (Prarthi 1973).

This effort to promote regional folklore took the same path as the Delhi Republic Day parade, and indeed Kullu dancers, too, participated in it. An undated photograph reproduced twice in the Dussehra Souvenir represents Indira Gandhi with her father Nehru, together with Kullu dancers.

In a message of felicitations addressed to the Dussehra committee, Chief Minister Parmar presents the Dussehra as a way of reassembling 'the century-old traditional heritage of the valley scattered over its hundreds of villages' (Parmar 1974). Such dispersed heritage is 'projected during this annual festival in which high and low, affluent and poor, sophisticated and rural folk all join in the celebrations to make it a "Commoners Celebration"”. Parmar's idea of the Kullu Dussehra as a place for gathering cultural differences within a regional and unified identity also appears as a district-level version of what Ashley, in relation to the Delhi national parade, calls Nehru's attempt 'to domesticate difference (on behalf of an) imaginary community of fellow countrymen' - corresponding to Nehru's motto for India: unity in diversity.

Along with the notion of Dussehra as a 'Mirror of Himachali Culture' (Kashyap 1971), an effort was also made to give the Kullu festival an international dimension. In 1973, a Romanian classical ballet troupe, and a women's wrestling team were scheduled to be part of the Dussehra cultural programme, which helped, according to the same Parmar, give Dussehra 'a prominent place on the cultural map of the world'.

The transformation of Dussehra into a cultural programme was not seen in a positive light by everybody. For instance, Deli Ram 
Shabab (1996), a Congress party MLA (Member of Legislative Assembly) and author of Kullu: Himalayan Abode of the Divine (1996) expressed a critical opinion about the transformation of Dussehra into a cultural programme, not without romantic nostalgia for the past:

No doubt, the participation of various cultural troops and artists sponsored by the State during Dussehra conveys to the people a sense of the country's unity in diversity, but the original charm and glamour of the festival is no longer present. Previously it was something unique to see the performance of folk dances by hill folk in their respective devta [deity] camps under a moonlit sky. That part of collective rejoicing and traditional coherence has been stolen by the cultural shows being organised in the mini-stadium, know as Kala Kendra (Shabab 1996: 98-99).

The need to preserve what is 'authentic' in spite of the transformations brought about by 'modernity', also seems to reflect a concern which Central leaders had addressed vis-a-vis the festival organisers. This becomes evident, for example, in a message of congratulations that Prime Minister Indira Gandhi sent to the Dussehra Souvenir of 1973. Here, she recommended that if the committee members wanted 'to give the younger generation a sense of pride in our cultural traditions, it was necessary to ensure that efforts to popularise and broaden the base of the festival were not made to the detriment of the authenticity of form and content'.

The discourse on 'heritage' and 'tradition' which fi gures in the volumes of the Dusshera Souvenir, reproduces the offi cial and ideological rhetoric that has accompanied the nationalisation of the festival. But it does not give an account of the local stakes that underlined this process. In the following section, I will try to bring them into light with the help of the narratives of those who participated or assisted in the transformation of Dussehra into a state-sponsored festival. 
Royal Roles and Artistic Patronage

All over India, the transformation of local festivals such as Dussehra into 'cultural heritage' has been promoted by regional governments via their local representatives. Political leaders not only patronised royal festivals but also, in some cases, tried to play a ritual role in the festival. This led to a tension or competition between local politicians and rajas whose former role was that of the patrons of these festivals. One example is reported by Peabody during the Kota's Ramlila in Rajasthan, an open-air pageant play that retells the victory of Ram over Ravan, and which is often performed during Dussehra. As the author explains, for a number of participants the Ramlila is more a celebration than a show. The gods who are represented are supposed to really incarnate themselves in the actors, who will in return be honoured by devotees and worshipped daily. But in 1986, the Ramlila ended up in political fighting - on the last day, when Ram sends an infl amed arrow to kill Ravan, two men, each with bow and quivers in their hands and each claiming to represent Ram, appeared before the effi gy of Ravan. One was the ancient king who, according to tradition, had to play the role of the god; the other was the local Congress MLA of the circumscription of Kota who, for that reason, demanded to take the place of the king during the representation, declaring that the time of kingship was over, and as the political leader it was now his right and duty to play the dramatic role of Ram (Peabody 1997: 559). Another case occurred in Mandi (Himachal Pradesh), where the king had sold the royal temple to the government after India's independence. Here, the local MLAs walk side by side with the king in the deity's procession taking place during an annual festival.

In Kullu, the relationship between the then royal descendant, Mohendar Singh, and the local MLA, Lal Chand Prarthi, was rather hostile. Though he had lost his privileges or titles, the Kullu king had remained the private owner of the royal temple of Raghunath to whom the festival was dedicated. As such, he continued to be the only protagonist of the procession and the ritual ceremonies, while district- and state-level politicians were now the honoured guests of 
the cultural programme, which they inaugurated with their political speeches. The festival indeed started to be - and still is - an ideal context where a political leader can in fact play a symbolic and crucial role.

As explained by Sharma, a former director of the Kala Kendra amphitheatre, one bone of contention between Prarthi and the raja was about the 'traditional way' in which village dances had to be performed. According to the king, village dances (natti) were traditionally performed exclusively by men, or whenever women danced too, they did it in a separate line. Not only did women not dance with men, but also low-status villagers or 'tribals' could not participate in the 'natti ring'. By contrast, continued Sharma, Prarthi's idea of 'tradition' referred to an 'original' or 'indigenous' way of dancing, which would have existed prior to the 'feudal period'. This is also shown by a passage of Prarthi's article Revival of Folk Culture, where he writes:

The folk dances had lost their originality, both in form and content. The females, who originally used to participate freely in the folk dances, had entirely withdrawn under the influence of wrong notions and artificially created social taboos by misinformed and illiterate people. To counteract this tendency, area-wise folk dance troupes were organised all over the district, both of males and females and the importance of the revival of original folk dances was explained to them (Prarthi 1973).

Though a Brahmin himself, Prarthi decided to open the natti dances to everybody, men, women and members of all castes. According to the instructions he had given to the dance committee for selecting the dancers participating in the dance competition, their choice was to be exclusively based on the artistic talents of the dancers, without taking into account their sex or caste. ${ }^{13}$ Prarthi's effort to liberalise dances is explicitly related to the participation of Kullu dancers in the folk dance performance held in Delhi on Republic Day.

With the celebration of Republic Day in 1950, and the holding of National Folk Dances, the Kullu Natti has become a member of the 
National Folk Dance Club, and has won the challenge shield on several occasions. With the emancipation of women due to the provision of equal rights with men in the constitution, they have now begun to participate in the 'open' Nattis. Their participation has become universal, much to the despair of some diehards and 'reactionaries'. In the same manner, members of scheduled castes and tribes, who were forbidden this social diversion of dancing in the past, have made their own deities and compete with their 'high caste' brethren in the Natti. One such team was declared the joint-winner in the Natti Competition of 1969.

But the disagreement between Prarthi and the king went much further than the controversy over liberalising the dances. The tension was about the intent of local politicians to put at their benefit the very logic of Dussehra in Kullu, as a way of ritually acting out, and displaying, a supremacy over more territorially fragmented powers scattered over the countryside.

As noticed by M. R. Thakur, a local erudite and former member of the Dussehra committee, behind Prarthi's effort to revitalise Dussehra was his underlying intention of taking control of the ritual aspects of the festival. By organising cultural programmes, Prathi's intention was also 'to attract villagers and their gods to the capital' (Thakur, interview). Part of the funds granted by the government for revitalising Dussehra was indeed assigned to village deities in the form of a gift (nazrana), on the condition that they would attend the festival, Thakur said.

Thus, whereas village deities were previously paying tribute to the king, they now received money from the state, via the Dussehra committee. The official and nominal invitation sent to village gods by the Dussehra committee indicated:

[We] hope that in order to maintain the tradition you will join Dussehra with pomp and glory [...] The Committee will assign the amount to be given to the different deities on the grounds of their prestige, the distance of their place from the capital and the number of persons who will accompany the deity to attend the festival.

It is thus on behalf of 'tradition' that deities are now requested to 
join the Dussehra festival. It is no longer an obligation but a prestige issue, and villagers compete so that their deities would receive the maximum amount of money and honours during the festival. The celebrations become an occasion for villagers to promote their deities' reputation in the region. Moreover, the festival allows politicians to establish political and electoral alliances with supporters of the deities' to whom they grant more money and honours.

In some ways, the intervention of local politicians for 'nationalising' Dussehra also aimed, through sponsoring the deities' participation, at getting rid of the royal character of the festival. This becomes clear in a message from Chief Minister Parmar, who contrasts the development of Dussehra as a 'Commoner's Celebration' with its previous feudal character (with reference to the royal period):

[...] With the changing times, the feudal patronage of the festival has ended giving place to a 'Commoner's festival'. Feudalism no longer guides the activities of the festival, instead, a State-level Dussehra Committee organises all the cultural activities in consultation with the people's representative which has altogether changed the complexion of the festivities from 'feudal-oriented to commoner-oriented' (Parmar 1974).

However, as we have seen, the local king continued to be the owner of the royal temple, and to be ritually honoured by all the village deities coming to Dussehra as the caribardar (staff bearer) of Raghunath. But Prarthi was not willing to accept this infl uence. As noted by Chambial, a Kullu schoolmaster and the former member of the Dussehra committee, Prarthi 'did not tolerate the fact that people in Kullu were still attributing more importance to the king than to a minister or MLA'. He thus tried to contest the presence of the king at the festival, saying that India was an independent country and that the king had no right to attend the festival.

The two positions were rather radical, with Prarthi stating that 
the king should no longer be the protagonist of the festival - he also tried once to contest his ownership of the Raghunath temple and the king declaring that 'this is the tradition', 'I am the first servant of the royal god and my duty is to maintain the rituals'. What was presented in Prarthi's rhetoric as an effort to preserve 'tradition' and to 'revitalise Kullu heritage', was now rejected by the person primarily concerned with this tradition: the king. The king was in fact very keen on maintaining 'tradition', but on the condition that he himself remained at its centre.

The tension between the king and Prarthi reached its climax during an episode in 1972, which is important to recall here in order to show how villagers as well as 'village gods acting through villagers' were far from being passive spectators but took an active part in the confrontation.

The Kala Kendra amphitheatre had been built by Prarthi on a piece of land which was formerly the property of a neighbouring king who had died with no heir, so that his property had passed to the state. A part of the plot of land was on the route where the king used to go in procession during Dussehra, accompanied by some of his closest village deities. The king did not want to alter the route for the procession, whereas Prarthi claimed that the place now belonged to the state, so they were not authorised to cross from there. In 1972, when the king ventured close to this limit, the police stopped him. Immediately, the palanquin of Hadimba, a well-known regional goddess and very close to the king, immediately started to move violently as a sign of protest, and made some incursions beyond the boundary. The police could not engage in preventing the deity from crossing the boundaries. This is also based on the notion that the deities direct their respective palanquin and they, not the villagers, are responsible for its movements. Palanquins also move very fast and violently, so nobody can stop them without being crushed. 
Some people who were present at the events remember the king being handcuffed by the police but he 'managed to break out of his handcuffs' - and people said that it was the goddess Hadimba who broke them. The king then started to tremble as a sign of divine possession, and spoke on behalf of Hadimba, addressing the representative of the government: 'This is my ancient path! You cannot stop us, we the gods! You must allow us to accomplish our ancient ritual!' Other people present at the site also became possessed and spoke in the name of their respective deity, criticising the government. Many other gods’ palanquins started to move and get angry, and together pushed back the policemen across the Kala Kendra's boundary, in order to perform their ritual on state property. However, in the fight that followed, the police opened fire and a man was killed. The celebrations were suspended.

The following year, this tension was still tangible, so the king refused to perform the rath yatra (the procession with god Ram in his float) as reported by an article in The Tribune newspaper, entitled 'Kulu Dussehra Dispute Unresolved':

The dispute between the chief "kardar" [administrator] of the deity Raghunathji, Mr Mohinder Singh, and the district authorities over the route of the procession to mark the beginning of Kulu Dussehra is continuing with only 24 hours left for the procession. Mr. Mohinder Singh told newsmen today that if the authorities did not allow the route of the procession he would not take part in it which would mean that the historic "rath yatra" [chariot procession] would not be organised. It may be added that last year it was the first time in about 300 years that the traditional "rath" [chariot] was not taken out because of this very trouble.

Eventually, the king decided not to hold the procession. Prarthi tried to take advantage of the situation by setting himself up as the head of the procession, but with an empty chariot (since the statue of Ram was part of the king's possession). Some five or six palanquins took part in the procession in which Prarthi also became possessed in order to seek divine legitimacy. This again shows that his intention was not to 'secularise' Dussehra, but rather to take the 
ritual role of the king during the festival by trying to celebrate the procession and adopt the ritual idiom of possession. Since a man had died in an accident the previous year, the dispute went to the court which ruled in favour of the king. After this decision, the separation of the ritual and the cultural part of the festival became more clear-cut.

In spite of Prarthi's efforts, the king succeeded in preserving his ritual control over the Dussehra festival. Prarthi and other Congress party politicians, who took control of the Dussehra committee after him, had to agree to restrict their presence and influence to the dance programmes only, and to leave the ritual celebrations to the king. The following reunification of religious and the cultural public spaces of Dussehra occurred only when the present king, Mahesvar Singh, son of Mahendar Singh, entered politics. He had been elected many times as candidate of the Hindu Rightist Bharatiya Janata Party (BJP), ${ }^{18}$ and each time could play on his dual role as king and chairman of the Dussehra committee. And even when he was not in power, the 'revitalisation of Dussehra' undertaken by Prarthi has eventually offered the king an excellent means of keeping alive the close links previously established with village deities, which he sought to convert into 'vote banks'. Printed Heritage and NewspaperReporters

As in other instances of 'heritage politics' (Ashley 1993), the attention given by Prarthi to folk dances in the official display of Kullu cultural heritage was but a selection of one element among many. The equivalence he made between heritage and folk dances had been explicitly formulated in one of his articles in 1971, where Kullu dances were considered 'to have carved a place of distinction in the country' and 'to preserve the cultural heritage in its originality'.

Along with folk dances, other elements of local culture were elevated to the rank of a specific regional 'heritage' and 'tradition', thanks to the development of the regional printing industry. The 1970s saw the start of the local publication of the Dussehra Souvenir, a series of booklets edited by the festival committee, 
whose main members were local government officers (deputy commission-ers, MLAs). As we have seen, the volumes of Dussehra Souvenir collect short articles from local educated persons and politicians. They engage in writing about aspects of regional culture, not only Dussehra and folk dances but also local deities and village temples, in relation with which notions like 'heritage' or 'tradition' are constantly evoked.

In a region like Kullu, where the expansion of the book market was rather weak until recently, the Dussehra Souvenir series represented early instances of debating and defining heritage. Thus, for several years, the 'printed discourse' about heritage and tradition was not widely accessible. Only a few representatives of the local political and intellectual milieu - those, in fact, who were invited by the Dussehra cultural committee to write in the publication had knowledge of these discourses.

A different and non-hegemonic discourse on heritage - with much wider circulation - is the one that emerged in the last 10 years through newspapers. Indeed, since the 1970s, the cultural programmes performed at the Kala Kendra have made Kullu Dussehra a media-worthy event. At the time of Dussehra, many Hindi and English newspapers from neighbouring regions and from Punjab send their reporters to Kullu in order to cover the full festival. Until recently, most of the articles were almost exclusively dedicated to the first day's spectacular chariot procession, as well as to the many cultural programmes which are performed at the Kala Kendra. However, what now seems to attract journalists increasingly is the possibility of voicing villagers' points of view about the festival, and eventually of writing extensive articles on village deities. Journalists often look for a good subject to write about by walking around the hundreds of tents that are temporarily erected in the town's main square to accommodate the deities' palanquins and the villagers. They meet and interview villagers, take photographs of their deity's palanquin, and collect stories. They may even decide to go to the deity's home village and report on this divine place of origin. Villagers greatly appreciate this kind of coverage. Much more than folk dance programmes, local deities are at the core of their territorial identity. This is also due to the 
social and political stakes which lie behind their cult.

In most cases, the deities chosen for the story are already wellknown in the valley - the most famous one is probably goddess Hadimba, who is considered to have founded the Kullu dynasty and to be the king's 'grandmother'. Photographs of Hadimba's palanquin, her temples and people may sometimes take up a whole page of the newspaper, with titles such as 'Dussehra cannot be celebrated without Hadimba'. ${ }^{21}$ But over the last years, more and more deities have become the subject of stories by journalists, including the so-called new deities (nai devta), for whom a cult has recently been set up in a village, or older deities (muafi dar devta, landowner deities) little known in the region and whom villagers would like to bring out of their anonymity. For example, the article 'Rishi appeared while children were playing,' ${ }^{22}$ explained how the deity's image (in stone) had been coincidentally found by children.

Coverage of Dussehra may even be exploited by some groups of villagers as a sort of showcase to allow them to amplify and to act out a conflict that may originally be more limited. This is the case, for example, in a longstanding feud between two neighbouring village deities, Shringa rishi (seer) and Balu nag (snake), who compete every year to get the most honourable place in the chariot procession - to the immediate right of Raghunath's chariot. For many years, the place has been assigned by the Dussehra committee to Shringa rishi, a village deity who exercises his jurisdiction over a territory included in an electoral circumscription of Kullu. By contrast, the supporters of Balu nag claim that 'traditionally', the rights belong to their god who is said to be the incarnation of Lakshman (Ram's brother). He thus holds the unquestionable right to walk next to his brother, they say. According to them, the decision of the Dussehra committee to assign the place to Shringa rishi instead of their god results from mere political and electoral interests. Every year, when Balu nag supporters take part in the procession, they push their god's palanquin amongst the crowd (claiming that it is the god who pushes them), thus forcing Shringa rishi's people to vacate the place while provoking a lot of disorder. A number of times, Balu 
nag's people have been arrested by the police, and for some years, the Dussehra committee along with the district commissioner even banned their deity from participating in the festival. However, all these 'repressive reactions' seem most welcome to Balu nag's supporters since they immediately make for sensational headlines with titles such as 'Deities at war' ${ }^{23}$; 'Balu nag has been stopped' 'Feud between devotees intensifies'. The conflict gets more and more coverage by the media. The name of Balu nag, who was quite unknown until some years ago, now appears daily in festival reports and even on the internet. Indeed, once news of such conflicts at festival time spread, journalists immediately rush to interview villagers and then report their own version in the press. In villagers' reports, notions such as 'traditions' or 'heritage' are constantly used. However, this time it is not in relation to the idea of revitalising and safeguarding a regional or nationwide cultural identity, but as rival arguments for defending what they claim to be their own deity's ritual privileges and rights.

Here is, for example, a passage from an article published in Amar Ujala (one of the most important Hindi newspapers of northern India), where the journalist takes sides with Balu nag's supporters following the decision by the administration to dismiss their request to stand to the right of the chariot:

In the Kullu Dussehra, the authenticity of the rules of this ancient tradition linked to devi, devta [village gods] are being broken one after another [...] The deities' functionaries who know this ancient tradition have tried to preserve it. But for political and administrative reasons, they cannot [...]. Balu nag's people say that the places for gods and goddesses during the Raghunath procession have to be chosen according to shastra (sacred texts) and tradition, so that in the future this Raghunath procession, very popular throughout the world, will maintain solemnity and respect.

What thus emerges in newspaper articles is a more controversial debate on 'heritage' and 'tradition' than the ideological and romantic one that politicians and members of the elite propose in the Dusshera Souvenir series. In both discourses, heritage and 
tradition are considered to be 'endangered' and in need of being safeguarded and defended. But whereas in the Dusshera Souvenir series politicians are presented as the custodians of Kullu's authentic heritage, in this kind of report they may found themselves accused by villagers of 'breaking their traditions' for the benefi $t$ of their personal political interests.

\section{Conclusion}

The promotion of local festivals as 'cultural heritage' - recently defined by the UNESCO as 'intangible heritage' — has catered to state- and regional-level nationalism, initially in Europe and later in post-colonial societies. Although the discourse of UNESCO does not have the same objectives, being more concerned with safeguarding cultural diversity than the formation of political nationalism, it shares and reinforces the same language of 'safeguarding', 'promoting', or 'keeping alive' the 'authenticity' of 'local traditions'.

In India, while the promotion of cultural heritage by Central politicians (for example on Republic Day in Delhi) aimed at developing a feeling of national 'unity in diversity' on the regional level, the problem of who should maintain these traditions became a matter of ritual and political contention. In the case of the Kullu Dussehra, the main protagonists were a local political leader, Prarthi, the main promoter of the Dussehra's revival, and the raja who, while gaining great benefit from the revitalisation of Dussehra, tried to oppose the government's efforts to take control of the festival. The episodes concerning the procession, as narrated here, show how the conflict regarding who should maintain the 'tradition' proved complex, involving not only the king and politicians, but also villagers and their village gods.

Indeed, the case of Dussehra presented here differs from other productions of heritage politics such as the darbar, an 'invented tradition' of Victorian India that was adopted by Indian Congress politicians (Haynes 1990) and then exported to West Africa in order to become an expression of Nigeria's national heritage (Apter 1999). In contrast with other cases of newly created rituals, which, 
to quote Peabody, are devoid of 'contextual complexity' (1997: 574), the Kullu Dussehra festival shows how the shift from ritual to heritage has been made through an appropriation of local religious logics, which in the past proved all their pertinence in legitimating political power.

The analysis of the Dussehra here also underlines the reciprocal interference between a 'culturalisation' process and ritual dynamics, with the latter taking over. This can be seen in relation to Raghunath, who continues to be the main protagonist of Dussehra, and who upholds the notion of Dussehra as a 'royal festival'. It may also be seen in relation to village gods, who make the most of the 'culturalisation' process by receiving 'cultural funding', but who can also, as we have seen in the case of Hadimba, interfere in this process by opposing it.

The patronage of the festival also highlights the ambiguous co-existence of ritual and cultural logics. Indeed, although village deities continue to pay homage to the king and to Raghunath, their participation in the festival is no longer due to the obligations they have towards the god and the king, but is an outcome of the Dussehra committee's appeal to keep the 'tradition' alive.

Local deities' involvement in the regional state-sponsored promotion of heritage is quite a widespread phenomenon in postindependence India. In nearby Uttarakhand, for example, Sax shows how over the last decades goddess Nanda Devi and her ritual processions have become an 'item of heritage' and the most important regional icon of the newly-formed regional state, promoted by government ministers and private entrepreneurs, publicised in audio and video cassettes 'to be marketed, sold, and consumed locally, nationally, and even internationally' (Sax, forthcoming).

Another example is that of Kerala (Tarabout 1997), where the extremely spectacular and elaborate teyyam possession rituals have been staged since the country's independence as 'folkloric dances', and have been promoted by the local Leftist government coalition as an integral part of Kerala culture and heritage. Teyyam's mediums (without being possessed) began to be engaged by entrepreneurs and festival organisers, and performed some 
so-called 'possession dances' entirely devoid of any religious or oracular dimension in a shortened, decontextualised and commercialised version. Due to their spectacular and aesthetically elaborate nature, which western tastes could identify as a form of 'primitive art', teyyam also received international acclaim by the 1980s.

Unlike teyyam, possession cults in Kullu have not undergone such a change. Deities' palanquins and mediums' oracular possession, although at the very heart of villagers' territorial, ritual and social identity, have not been staged out of context, within a local or national cultural programme. As I argued earlier, what was selected instead for this purpose were the entertaining parts of the rituals - village dances - which have been perceived as artistic expressions worthy of a staged performance. Although, like teyyam, once transformed into cultural programmes, village dances have also been shortened, commercialised and adapted to an urban audience, they were not elaborate enough to become exportable artistic forms. Indeed, the so-called 'internationalisation' of Kullu Dussehra corresponds to the creation of an international context at home by inviting dancers from abroad so that Dussehra may proudly be proclaimed an 'International Folk Dance Festival'.

This process has no significant repercussions on the deities' cults proper, as dances have been separated from their ritual context and transformed into prize-winning competitions. It is by playing on this separation that Kullu's post-independence politicians wanted to control the festival while ridding it of its royal connotations. However, they only partly succeeded in doing so. Indeed, the promotion of Dussehra as cultural heritage has involuntary created the conditions for adapting royal culture, based on politico-religious alliances between the king and village gods, to the political system of contemporary India.

Notes

1 Some passages in the first part of this paper are adapted and 
translated from a previous French publication (Berti 2005). 2 In various parts of India, village temple deities have land registered in their name (Sontheimer 1964; Annoussamy 1979). They are also perceived as kings ruling over their respective territories and receive a regular tribute (nazrana) from those who live within their jurisdiction. In Kullu, they exercise their sovereignty through a set of various representatives. First, they can be consulted directly by addressing them through their institutional medium. Second, they are officially represented by their administrator, the kardar, who manages their land properties and who is responsible for the organisation of their cult. Third, gods have their own palanquin, a wooden structure decorated with metal faces and coloured cloths. The palanquin, like the medium, is considered to be the receptacle of the god, and its movements are said to be directed by the god himself and not by its bearers - who are in most cases highcaste villagers. Still a further way for the god to express his will is by manifesting himself through ordinary people of his jurisdiction.

3 Registers in Urdu at the beginning of the 20th century, recording the quantity of land owned by each divinity, thus indicate the amount that each had to pay to Raghunath. When the British took control of the region in 1846, they testified to the Dussehra's annual gathering, and to how, even during their direct rule, tribute to Raghunath was still given annually.

4 Interview with Sharma, 2000.

5 Some articles echo this local perception, such as 'Kullu Dussehra Past and Present' (Gupta 1972), or 'Kullu Dussehra Then and Now' (Prarthi 1973). The authors explain how land reforms, by offering cultivators the opportunity of becoming owners of the land they cultivated, had thrown many of these village gods into poverty since they lost the rights over land cultivated by those looking after their temple.

6 Dussehra Souvenir, 1973.

7 In a comparative perspective, see Thiesse (2001) on the importance given to folklore for the formation of European nationalisms.

8 The Tribune, 26 November 1922, Himachal Pradesh. 
9 The role of this institute is, among other things, to make a fi rst selection of dance troupes from the various Indian states in order to draw up the six-day programme.

10 Interview with Sharma, 2000.

11. Dussehra Souvenir, 1970.

12. Dussehra Souvenir, 1974.

13. Interview with Sharma, 2000.

14. Dussehra Souvenir, 1974.

15. Interview with Prarthi, 2000.

16. Interview with Chambial, 2000.

17. The Tribune, 7 October 1973, Himachal Pradesh.

18. The BJP (Bharatiya Janata Party, which literally means 'party of the Indian people') has adopted a strategy of mass mobilisation 'by using forms of manifestations borrowed from a religious register of procession and pilgrimage'(Jaffrelot 1993: 10; also Assayag 2001). However, the choice to present kings on the electoral list is not limited to this Hindu Right-wing party. If at the beginning, the Congress had forbidden proposing the kings on their lists, by 1957 it 'offered its investiture to many princes who were still very popular and influent' (Hurtig 1988: 66; see also Jaffrelot 1993 and Sundar 2001).

19. The term 'vote bank' was introduced by the Indian sociologist Srinivas to indicate a bloc of votes based on caste lines or other factors (religious, linguistic etc.) creating political loyalty. On the creation of vote banks in Kullu, see Berti 2009a and 2009b.

20. Dussehra Souvenir, 1971.

21. Divya Himachal, 23 October 2004.

22. Amar Ujala, 26 October 2004, Chandigarh.

23. The Indian Express, 29 October 2001.

24. Amar Ujala, 24 October 2004, Chandigarh.

25. The Tribune, 25 October 2004, Himachal Pradesh.

26. Amar Ujala, 14 October 2000, Chandigarh. 


\section{References}

Apter, A. 1999. 'The Subvention of Tradition: A Genealogy of the Nigerian Durbar', in G. Steinmetz (ed.), State/Culture. State-Formation after the Cultural Turn, pp. 213-52. Ithaca and London: Cornell University Press.

Ashley, W. 1993. 'Recodings: Ritual, Theatre, and Political Display in Kerala State'. Unpublished thesis, University of New York.

Berti, D. 2005. “"Now It Is All Politics”. Quelques discours sur les Transformations d'une fête royale en Inde du Nord', in G. Colas and G. Tarabout (eds), Rites Hindous: Transferts et Transformations, pp. 305-42. Paris: Ehess.

. 2009a. 'Divine Jurisdictions and Forms of Government in North India', in D. Berti, D. and G. Tarabout (eds), Territory, Soil and Society in South Asia. New Delhi: Manohar.

. 2009b. 'Kings, Gods and Political Leaders in Kullu (Himachal Pradesh)', in M. Lecomte-Tilouine (ed.), Bards and Mediums in the Khas Kingdoms, pp. 395. Almora: Almora Book Depot.

Granoff, P. 2001. 'My Ritual, My Gods: Ritual Exclusivism in Medieval India’. Journal of Indian Philosophy, 29(1-2): 109-31. Gupta, V.P. 1972. 'Kulu Dussehra Past and Present', in Dussehra Souvenir Kullu: A.K. Mohapatra.

Haynes, E.S. 1990. 'Rajput Ceremonial Interactions as a Mirror of a Dying Indian State System 1820-1947’, Modern Asian Studies, 24(3): 459-92.

Jain, J, 2008. India's Republic Day Parade: Restoring Identities, Constructing the Nation. Mumbai: Marg Publications.

Kashyap, P. C. 1971. 'Dussehra. A Mirror of Himachali Culture', Dussehra Souvenir, Kullu: A.K. Mohapatra.

Kirshenblatt-Gimblett, B. $1995 . \quad$ 'Theorizing Heritage', Ethnomusicology, 39(3): 367-80.

Kulke, H. 1986 [1978]. 'Early Royal Patronage of the Jagannatha Cult', in A.

C. Eschmann, H. Kulke and G. C. Tripathi (eds), The Cult of Jagannath and the Regional Tradition of Orissa, pp. 139-55. New 
Delhi: Manohar. Krauskopff, G. and M. Lecomte-Tilouine (eds). 1996. Célébrer le Pouvoir. Dasai, une fête Royale au Népal. Paris: CNRS. Parmar, Y. S. 1974. 'Kulu Dussehra becomes International Festival', Dussehra Souvenir. Kullu: A. K. Mohapatra. Peabody, N. 1997. 'Inchoate in Kota? Contesting Authority Through a North Indian Pageant-play’, American Ethnologist, 24(3): 559-84. Prarthi, L. C. 1970. 'History and Legend of Kulu', Dussehra Souvenir, Kullu: Mohapatra.

-. 1973. 'Revival of Folk Culture', Dussehra Souvenir, Kullu: A. K. Mohapatra.

Prarthi, L. C. 1974. 'Kullu Dussehra Then and Now', Dussehra Souvenir, Kullu: A. K. Mohapatra.

Sax, W. (forthcoming). 'Religion, Ritual, and Ways of Belonging: The Case of Uttarkhand', in J. Pfaff and G. Toffi n (eds), Citizenship, Democracy, and Belonging in the Himalayas, New Delhi: Sage.

Shabab, D. 1996. Kullu. Himalayan Abode of the Divine. New Delhi: Indus Publishing Company.

Singh, M. G. 1996. Festivals, Fairs and Customs of Himachal Pradesh. Delhi: Indus Publishing Company.

Tarabout, G. 1997. 'La mise en Culture des Rites', Cultures en Mouvement, 5: 40-43.

Thiesse, A. M. 2001. La Création des Identités Nationales Europe XVIII-XX Siecle, Paris: Editions du Seuil. 